\title{
DIAMETRAL TENSILE STRENGTH AND WATER SORPTION OF GLASS-IONOMER CEMENTS USED IN ATRAUMATIC RESTORATIVE TREATMENT
}

\author{
RESISTENNCIA À TRAÇÃO DIAMETRAL E SORÇÃO DE ÁGUA DE CIMENTOS \\ DE IONÔMERO DE VIDRO USADOS NO TRATAMENTO RESTAURADOR \\ ATRAUMÁTICO
}

\author{
Daniela Francisca Gigo CEFALY \\ $\mathrm{PhD}$ student. \\ Eduardo Batista FRANCO \\ $\mathrm{PhD}$, professor of Operative Dentistry. \\ Rafael Francisco Lia MONDELLI \\ $\mathrm{PhD}$, professor of Operative Dentistry. \\ Paulo Afonso Silveira FRANCISCONI \\ $\mathrm{PhD}$, professor of Dental Materials. \\ Maria Fidela de Lima NAVARRO \\ $\mathrm{PhD}$, professor of Operative Dentistry. \\ Department of Operative Dentistry, Bauru Dental School, University of São Paulo.
}

\begin{abstract}
7 he purposes of this study were to evaluate the diametral tensile strength and the water sorption of restorative
1 (Fuji IX and Ketac Molar) and resin-modified glass-ionomer luting cements (ProTec Cem, Fuji Plus and Vitremer) mixed at both manufacturer and increased powder: liquid ratio, for their use in the Atraumatic Restorative Treatment. A conventional restorative glass-ionomer (Ketac Fil) was used as control. Specimens $(6.0 \mathrm{~mm}$ in diameter x $3.0 \mathrm{~mm}$ in height) were prepared and stored (1 hour, 1 day and 1 week) for a diametral tensile strength test. Data were subjected to two-way ANOVA and Tukey tests $(\mathrm{p}<0.05)$. For the water sorption test, specimens of $15.0 \mathrm{~mm}$ in diameter $\times 0.5 \mathrm{~mm}$ in height were prepared and transfered to desiccators until a constant mass was obtained. Then the specimens were immersed in deionized water for 7 days, weighed and reconditioned to a constant mass in desiccators. Data were subjected to one-way ANOVA and Tukey tests $(\mathrm{p}<0.05)$. Five specimens of each studied material and consistency were prepared for each test. The resin-modified glass-ionomer cements showed significantly higher strength than the conventional materials. Except for ProTec Cem, the diametral tensile strength of the resinmodified materials significantly increased from luting to restorative consistency. Except for ProTec Cem, the water sorption of the resin-modified glass ionomers was higher than the others. The water sorption of resin-modified materials at restorative consistency was significantly lower than at luting consistency. Resin-modified glass-ionomer luting cements mixed at increased powder: liquid ratio showed better properties than at luting consistency.
\end{abstract}

UNITERMS: Glass-ionomer cements; Atraumatic restorative treatment; Diametral tensile strength; Water sorption. 


\section{INTRODUCTION}

Although dental caries have decreased substantially in the industrialized countries, it remains a widespread problem. Many communities have no access to dental care due to absence of required equipment, electricity and pressurized water. A new method for treating dental caries, named Atraumatic Restorative Treatment (ART), has been used in these less developed areas. ART consists of removing carious tooth structure with hand instruments only and restoring the cavity with adhesive filling material, currently a glass-ionomer cement (GIC). Several recent studies have demonstrated the success of the ART technique under field conditions in less developed countries ${ }^{6,7,18}$.

This technique has been a short-term successful treatment for one-surface restorations ${ }^{6,7}$. However, the success decreases with time and with greater than onesurface restorations ${ }^{7,18}$. Better performance of these restorations might be obtained with resin-modified glass-ionomer cements (RM GICs).

Resin-modified glass-ionomer luting cements would be a good option once they set by an auto-cure of the resin phase and by the acid-base reaction. These cements have been tested at increased powder: liquid ratio for restorative consistency for ART use ${ }^{5}$.

ProTec Cem, a recently introduced resin-modified glass-ionomer luting cement has been studied ${ }^{4,21}$. This new material has shown better properties than the other resin-modified glass-ionomer luting cements with respect to its dimensional stability after water storage ${ }^{21}$. Water sorption is a critical property for direct restoratives because it increases the volume of the material. Moreover, water acts as a plasticizer, increasing the deterioration of the resin matrix. In addition, water sorption usually decreases color stability since water-soluble monomers can penetrate the restoration. However, no study on the mechanical strength of this new cement has been found. One of the most common mechanical properties reported for GICs is tensile strength ${ }^{2,10,11,12}$. Tensile strength has been determined through an indirect tensile test because of its relative simplicity and reproducibility of results. As there is no report regarding tensile strength and water sorption of this new cement at restorative consistency it would be important to make this information available. In addition, other available resin-modified glass ionomer luting cements should be tested at increased powder: liquid ratio aiming their use on ART technique. Such ratio increasing may produce a restorative consistency mixture that may result in lower water sorption and higher diametral tensile strength.

Consequently, the purpose of this work was to study the diametral tensile strength and the water sorption of restorative glass-ionomers and resin-modified glassionomers luting cements mixed at both manufacture and increased powder: liquid ratio for their use in the ART.

\section{MATERIAL AND METHODS}

Six GICs were used in this study (Table 1).

\section{Diametral Tensile Strength Test}

Five specimens of $6.0 \mathrm{~mm}$ in diameter and $3.0 \mathrm{~mm}$ in height were prepared for each material/consistency and each test period (1 hour, 1 day and 1 week). All the samples were made according to ADA specification number $27^{1}$. The environmental temperature was controlled and the materials were mixed with a plastic instrument on an impermeable paper. After mixing, the cements were put into plastic capsules and injected by syringe (Centrix) into stainless steel moulds, which were previously coated with a nonreactive lubricant (solid vaseline). The moulds were slightly over-filled with the materials. A piece of film was placed onto the material in the mould and covered with a glass slide. Hand pressure was then applied for 20 seconds while excess material was extruded from the top of the mould. Two minutes after the start of the mix, the assembly was placed in an oven at $37 \pm 1{ }^{\circ} \mathrm{C}$ and $95 \pm 5 \%$ relative humidity, for 15 minutes. Then, the specimens were ejected from the mould and stored in $6 \mathrm{~mL}$ of deionized water at $37 \pm 1^{\circ} \mathrm{C}$. The diametral tensile strength was performed after 1 hour, 1 day and 1 week of storage. Tests were made in a Kratos Universal Testing Machine (Kratos Equipments K 2000 MP São Paulo, Brazil, 06790-080). The diametral tensile strength (DTS) [kgf/ $\mathrm{cm}^{2}$ ] was calculated as follows: DTS $=2 \mathrm{~L} / \mathrm{pdh}$, where $\mathrm{L}$ is the load at fracture [kgf], $\mathrm{p}=3.14, \mathrm{~d}$ is the diameter of the samples $[\mathrm{cm}]$ and $\mathrm{h}$ is the height of the samples $[\mathrm{cm}]$. DTS values $\left[\mathrm{kgf} / \mathrm{cm}^{2}\right]$ were converted into MPa as follows: DTS $[\mathrm{MPa}]=$ DTS $\left[\mathrm{kgf} / \mathrm{cm}^{2}\right]$ x 0.09807. Data were subjected to two-way analysis of variance (ANOVA) and a Tukey test for multiple comparisons $(\mathrm{p}<0.05)$.

\section{Water Sorption Test}

The tests were based on ISO 4049: $1988(\mathrm{E})^{2}$. The powder and liquid were weighed, and after mixing, the materials were injected by syringe (Centrix) into stainless steel moulds. The moulds were slightly overfilled with the materials. A piece of film was placed onto the material in the mould and covered with a glass 
slide. Hand pressure was then applied for 20 seconds while excess material was extruded from the top of the mould. Five specimens $(15 \mathrm{~mm}$ in diameter and $0.5 \mathrm{~mm}$ in height) were prepared for each product and ratio. Two minutes after the start of the mix, the assembly was placed in an environment of $37 \pm 1{ }^{\circ} \mathrm{C}$ and $95 \pm 5 \%$ relative humidity for 15 minutes. Then, the specimens were ejected from the moulds and stored in a desiccator maintained at $37 \pm 1{ }^{\circ} \mathrm{C}$. After 24 hours, the specimens were transfered to a desiccator maintained at $23 \pm 1{ }^{\circ} \mathrm{C}$ for 1 hour and weighed on an analytical balance $(0.0001$ g accuracy) (Mettler Toledo, AB204, Switzerland). This cycle was repeated until a constant mass was obtained. The specimens were immersed in deionized water and maintained at $37{ }^{\circ} \mathrm{C}$ for 7 days. After this period, the specimens were removed, washed with water, dried with absorbent paper, waved in air for $15 \mathrm{~s}$ and weighed 1 minute after removal from water $\left(\mathrm{M}_{1}\right)$. After this weighing, the specimens were reconditioned to constant mass $\left(\mathrm{M}_{2}\right)$ in desiccators using the cycle described before. The volume $(\mathrm{V})$ of each specimen was calculated in cubic millimeters. The water sorption (WS) was determined using the following equation: $\mathrm{WS}=\left(\mathrm{M}_{1}-\mathrm{M}_{2}\right) /$ $\mathrm{V}$. The values were expressed in $\mathrm{mg} / \mathrm{mm}^{3}$. Data were subjected to one-way analysis of variance (ANOVA) and a Tukey test for multiple comparisons $(p<0.05)$.

\section{RESULTS}

\section{Diametral Tensile Strength}

The results are shown in Figure 1.

Except for ProTec Cem, all materials showed an increase in DTS between the 1 hour and 1 week periods $(p<0.05)$. Ketac Molar, Ketac Fil and Fuji IX presented lower strengths than the RM GICs mixed at restorative consistency $(p<0.05)$. There was no significant difference between Ketac Molar and Fuji IX at the 3 tested periods. After 1 hour, Ketac Fil showed lower strength than Fuji IX ( $p<0.05)$. After 1 day, Ketac Fil showed lower strength than Fuji IX and Ketac Molar ( $\mathrm{p}<0.05)$.

Fuji Plus and ProTec Cem presented the highest strengths for the 1 hour and 1 day periods $(p<0.05)$. After 1 week period, they also presented the highest strengths but there was no significant difference between ProTec Cem and Vitremer.

Except for ProTec Cem, the diametral tensile strength of the resin-modified materials significantly increased from luting to restorative consistency.

\section{Water Sorption}

The results are presented in Figure 2.

Except for ProTec Cem, the RM GICs had significantly higher water sorption than the conventional and high-viscosity materials $(p<0.05)$.

For resin-modified materials, the restorative

TABLE 1- List of studied materials

\begin{tabular}{|c|c|c|c|c|}
\hline Product & Description & Powder: liquid ratio & Manufacturer & Batch \# \\
\hline Fuji IX (FIX) & $\begin{array}{l}\text { Restorative - } \\
\text { high viscosity }\end{array}$ & $3.6 \mathrm{~g}: 1.0 \mathrm{~g}$ - manufacturer & $\begin{array}{l}\text { GC } \\
\text { Corporation, } \\
\text { Tokyo, Japan }\end{array}$ & 240481 \\
\hline Fuji Plus (FP) & Luting - & $2.0 \mathrm{~g}: 1.0 \mathrm{~g}$ - manufacturer & GC & $170381 /$ \\
\hline Fuji Plus restorative (FPr) & resin-modified & $3.0 \mathrm{~g}: 1.0 \mathrm{~g}$ - increased & $\begin{array}{l}\text { Corporation, } \\
\text { Tokyo, Japan }\end{array}$ & 160381 \\
\hline Ketac Fil (KF) & $\begin{array}{l}\text { Restorative - } \\
\text { conventional }\end{array}$ & $3.1 \mathrm{~g}: 1.0 \mathrm{~g}$ - manufacturer & $\begin{array}{l}\text { ESPE, Seefeld, } \\
\text { Germany }\end{array}$ & $\begin{array}{l}\text { FW0051013/ } \\
0050630\end{array}$ \\
\hline Ketac Molar (KM) & $\begin{array}{l}\text { Restorative - } \\
\text { high viscosity }\end{array}$ & $3.0 \mathrm{~g}: 1.0 \mathrm{~g}$ - manufacturer & $\begin{array}{l}\text { ESPE, Seefeld, } \\
\text { Germany }\end{array}$ & FW0048756 \\
\hline $\begin{array}{l}\text { ProTec Cem (PC) } \\
\text { ProTec Cem restorative (PCr) }\end{array}$ & $\begin{array}{l}\text { Luting - } \\
\text { resin-modified }\end{array}$ & $\begin{array}{l}2.25 \mathrm{~g}: 1.0 \mathrm{~g} \text { - manufacturer } \\
3.0 \mathrm{~g}: 1.0 \mathrm{~g} \text { - increased }\end{array}$ & $\begin{array}{l}\text { Vivadent, Schaan/ } \\
\text { Liechtenstein } \\
\text { 3M Dental }\end{array}$ & $14316 / 14308$ \\
\hline $\begin{array}{l}\text { Vitremer }(\mathrm{V}) \\
\text { Vitremer restorative }(\mathrm{Vr})\end{array}$ & $\begin{array}{l}\text { Luting - } \\
\text { resin-modified }\end{array}$ & $\begin{array}{l}1.6 \mathrm{~g}: 1.0 \mathrm{~g} \text { - manufacturer } \\
3.0 \mathrm{~g}: 1.0 \mathrm{~g} \text { - increased }\end{array}$ & $\begin{array}{l}\text { Products, St. } \\
\text { Paul, MN, USA }\end{array}$ & $9590 / 9147$ \\
\hline
\end{tabular}


consistency promoted significantly lower water sorption than the luting consistency.

Among the resin-modified glass-ionomer cements, ProTec Cem had the lowest water sorption $(\mathrm{p}<0.05)$. Its water sorption was not significantly different from that of the conventional GIC Ketac Fil and was lower than that of the high viscosity GIC, Fuji IX.

\section{DISCUSSION}

In this experiment, a special device was constructed to make it easier to position the specimens, with its diameter coinciding with the direction of the compressive force from the platforms of the machine. All the tested samples presented a failure plane, which divided the specimens into two equal parts, confirming that the data are valid.

Except for ProTec Cem, all materials showed an increase in DTS between 1 hour and 1 week and between 1 day and 1 week. This increase can be explained by the setting reaction of glass ionomer cements. The calcium polycarboxylate is formed in the first 5-7 minutes after mixing. The aluminum polycarboxylate, which is more stable and improves the mechanical properties of the cement, takes a mean of 24 hours to be formed. The setting reaction continues for at least 24 hours and probably much longer ${ }^{17,26}$. In the present study, the specimens were immersed in water 15 minutes after the start of mix. It probably was a short period mainly for conventional glass-ionomers. The DTS may have been negatively affected. However this study followed the ADA specification number 27 which recommends such period. It permits standardization of specimens and comparison of results with those from literature.

The luting RM GICs tested at increased powder:

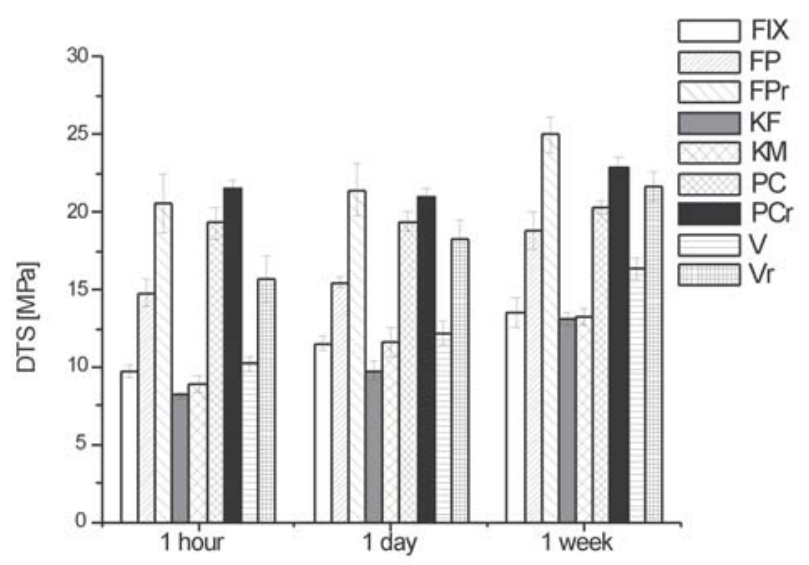

FIGURE 1- Diametral tensile strength of the studied glassionomer cements liquid ratio ( $\mathrm{FPr}, \mathrm{PCr}$ and $\mathrm{Vr}$ ) showed better strengths than the conventional GIC (KF) and the GIC marked for ART ( $\mathrm{F}$ and $\mathrm{KM}$ ). These results are in agreement with those of Ewoldsen, Covey, Lavin ${ }^{5}$ whom showed that the RM GICs mixed at increased powder: liquid ratio exhibited better properties than the conventional GICs.

Resin-modified GICs have two mechanisms of setting: the acid-base setting reaction and a polymerization reaction ${ }^{27}$. This last one is a self-cure reaction of the resin phase for the luting glass-ionomer cements. Resin-modified GICs were developed to improve the mechanical properties of the conventional materials ${ }^{12,15,25}$ and overcome their early moisture sensitivity ${ }^{12,27}$. These materials have shown higher DTS than conventional GICs ${ }^{13,25}$.

Conventional GICs are not only strongly hydrophilic but also can dehydrate if exposed to the air, mainly in the initial stages of the setting reaction ${ }^{3,20}$. As water gain or loss may cause to the restoration permanent damage, surface protector agents are indicated ${ }^{14}$.

Water has an important role in the cement. It is responsible for the transport of calcium and aluminum cations, which will react with the polyacid to form a polyacrylate matrix ${ }^{28}$. If water is lost, due to desiccation, the reactions may stop and surface crazing may occur $^{14,28}$. On the other hand, early moisture contamination results in loss of substance as well as reduction of physical properties and loss of translucency $y^{3,16,19}$.

Although the need for protection of conventional GICs is well known, there is a controversy with resinmodified ionomers. It is believed that the formation of an organic matrix protects them against the early contamination by water ${ }^{28}$. However, Um, Oilo ${ }^{24}$ observed that increasing the time after the start of mixing before water immersion resulted in less solubility and

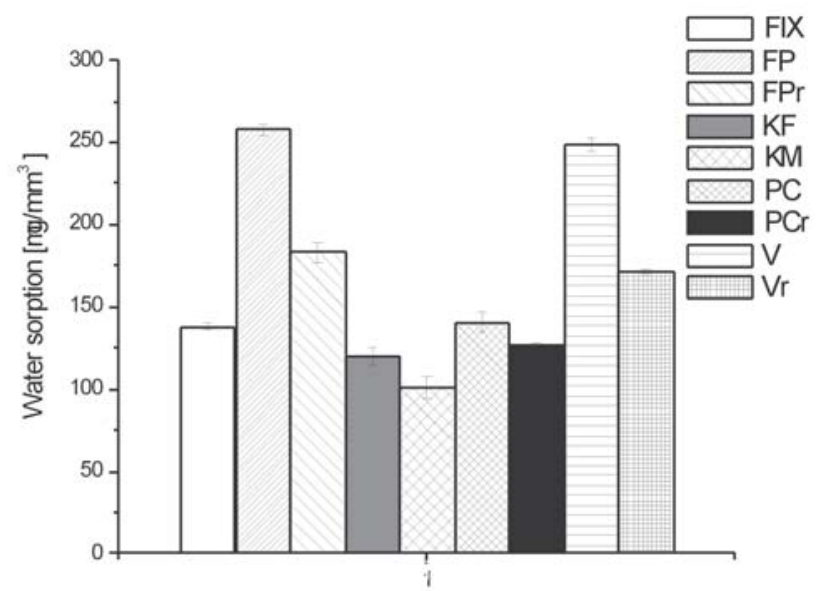

FIGURE 2- Water sorption of the studied glass-ionomer cements 
setting changes of the RM GIC studied. Although the time effects before water immersion were less noticeable in the RM GIC, it was shown that these materials are also water sensitive in the early setting stages. Studies have shown a correlation between the decrease in the physical properties of RM GICs and the water uptake ${ }^{2,23}$. Sorbed water probably behaves as a plasticizer, changing failure mode of the specimens and reducing their mechanical strength. Moreover, the water sorption usually decreases color stability because watersoluble stains can penetrate the restoration. Although a significant decrease in water sorption was observed from luting to restorative consistency, the studied RM GICs, except ProTec Cem, had significantly higher water sorption than the conventional ones, as observed by others ${ }^{9,23}$. The water is replaced by a water/2hydroxyethylmethacrylate (HEMA) in RM GICs and HEMA is hydrophilic in nature. However, ProTec Cem had significantly lower water sorption than the other RM GICs. Its water sorption was also lower than that of the high viscosity ionomer, Fuji IX, and was not significant different from that of the conventional ionomer Ketac Fil. A lower water sorption and a consequent lower expansion of PC are claimed by its manufacturer ${ }^{22}$. This feature is the result of its dense network structure in combination with an optimum filler content. The water content of this material has been determined in a way that the material is saturated after polymerization and thus no longer absorbs water.

The ART treatment has been successfully performed in less developed areas. Nowadays, its indication includes handicapped persons, pregnant women, old people and any person with some difficulty in locomotion. However, the longevity of ART restorations needs to be increased as well as the success of multi surface ART restorations ${ }^{7,18}$. Once the resin-modified glass-ionomer luting cements at increased powder: liquid ratio presented better DTS than the conventional materials, the success of ART restorations could be better with their use. ProTec Cem might be even a better option due to its lower water sorption than the other studied RM GICs. Other properties of such material need to be investigated and clinical studies need to be conducted with resin-modified glass-ionomer luting cements at increased powder: liquid ratio.

\section{CONCLUSION}

The resin-modified glass-ionomer cements showed significantly higher strength than the conventional materials. Except for ProTec Cem, the diametral tensile strength of the resin-modified materials significantly increased from luting to restorative consistency. Except for ProTec Cem, the water sorption of the resin-modified glass ionomers was higher than the others. The water sorption of resin-modified materials at restorative consistency was significantly lower than at luting consistency. Resin-modified glass-ionomer luting cements mixed at increased powder: liquid ratio showed better properties than at luting consistency.

\section{RESUMO}

Avaliou-se a resistência à tração diametral e a sorção de água de cimentos de ionômero de vidro restauradores (Fuji IX e Ketac Molar) e modificados por resina indicados para cimentação (ProTec Cem, Fuji Plus e Vitremer) manipulados na proporção pó: líquido indicada pelo fabricante e em maior proporção para a utilização no Tratamento Restaurador Atraumático. O ionômero restaurador convencional (Ketac Fil) foi utilizado como controle. Espécimes $(6,0 \mathrm{~mm}$ de diâmetro x 3,0 mm de altura) foram preparados e armazenados (1 hora, 1 dia e 1 semana) para o teste de resistência à tração diametral. Os dados foram submetidos a ANOVA a dois critérios e ao teste de Tukey $(\mathrm{p}<0,05)$. Para o teste de sorção de água, espécimes com $15,0 \mathrm{~mm}$ de diâmetro x $0,5 \mathrm{~mm}$ de altura foram preparados e transferidos a dessecadores até a obtenção de uma massa constante. Em seguida, os espécimes foram imersos em água deionizada por 7 dias, pesados e recondicionados a uma massa constante em dessecadores. Os dados foram submetidos a ANOVA a um critério e ao teste de Tukey $(\mathrm{p}<0,05)$. Cinco espécimes de cada material e consistência foram preparados para cada teste. Os ionômeros modificados por resina mostraram maior resistência que os convencionais. Exceto pelo ProTec Cem, a resistência dos materiais modificados por resina significativamente aumentou da consistência cimentante para a restauradora. Exceto pelo ProTec Cem, a sorção de água dos ionômeros modificados por resina foi maior que a dos outros ionômeros. A sorção de água dos materiais modificados por resina na consistência restauradora foi significativamente menor que na consistência de cimentação. Os cimentos de ionômero de vidro modificados por resina indicados para cimentação manipulados em maior proporção pó: líquido apresentaram melhores propriedades que na consistência de cimentação.

UNITERMOS: Cimentos de ionômero de vidro; Tratamento restaurador atraumático, Resistência à tração diametral; Sorção de água. 


\section{ACKNOWLEDGEMENT}

The present study was supported by FAPESP Fundação de Amparo à Pesquisa do Estado de São Paulo - Brazil (Grant \#98/15709-3).

\section{REFERENCES}

1- American Dental Association. Council on Dental Material. Specification no 27 for direct filling resins. J Amer Dent Ass 1977; 94:191-4.

2- Cattani-Lorente MA, Dupuis V, Moya F, Payan J, Meyer JM. Comparative study of the physical properties of a polyacid-modified composite resin and a resin-modified glass-ionomer cement. Dent Mater 1999; 15:21-32.

3- Causton BE. The physico-mechanical consequences of exposing glass ionomer cements to water during setting. Biomaterials 1981; 2:112-5.

4- de Gee AJ, Bruney K, Feilzer AJ, Davidson CL. Hygroscopic expansion stress determination of resin-modified glass-ionomers. J Dent Res 2000; 79:540.

5- Ewoldsen N, Covey D, Lavin M. The physical and adhesive properties of dental cements used for atraumatic restorative treatment. Spec Care Dentist 1997; 17:19-24.

6- Frencken JE, Makoni E, Sithole WD. Atraumatic restorative treatment and glass-ionomer sealants in an oral health programme in Zimbabwe: evaluation after 1 year. Caries Res 1996; 30:428-33.

7- Frencken JE, Songpaisan Y, Phantumvanit P, Pilot, T. An atraumatic restorative treatment (ART) technique: evaluation after one year. Int Dent J 1994; 44:460-4.

8- International Standard Organization. Dentistry - resin based filling materials-ISO 4049:1988 (E). Geneva, 1988.

9- Iwami Y, Yamamoto H, Sato W, Kawai K, Torii M, Ebisu. Weight change of various light-cured restorative materials after water immersion. Oper Dent 1998; 23:132-7.

10- Kerby RE, Knobloch L. Strength characteristics of glass-ionomer cements. Oper Dent 1992; 17:170-4.

11- Kerby RE, Knobloch L, Thakur A. Strength properties of visiblelight-cured resin-modified glass-ionomer cements. Oper Dent 1997; 22:79-83.

12- Mathis RS, Ferracane JL. Properties of a glass-ionomer/resincomposite hybrid material. Dent Mater 1999; 5:355-8.

13- McCarthy MF, Hondrum SO. Mechanical and bond strength properties of light-cured and chemically cured glass ionomer cements. Am J Orthod Dentofacial Orthop 1994; 105:135-41.

14- McLean JW. Clinical applications of glass-ionomer cements. Oper Dent 1992; 5:184-90.
15- Mitra SB. Adhesion to dentin and physical properties of a lightcured glass-ionomer liner/base. J Dent Res 1991; 70:72-4.

16- Oilo G. Early erosion of dental cements Scand J Dent Res 1984; 92:539-43.

17- Pearson GJ, Atkinson AS. Long-term flexural strength of glassionomer cements. Biomaterials 1991; 12: 658-60.

18- Phantumvanit P, Songpaisan Y, Pilot T, Frencken, JE. Atraumatic restorative treatment (ART): a three-year community field trial in Thailand - survival of one surface restorations in the permanent dentition. J Publ Hlth Dent 1996; 56:141-5.

19- Phillips S, Bishop BM. An in vitro study of the effect of moisture on glass ionomer cement. Quintessence Int 1985; 16:175-7.

20- Saito S. Characteristics of glass ionomer and its clinical application. Relations between hardening reactions and water. Int $\mathrm{J}$ Dent Mater 1978; 8:1-16.

21-Salz U, Rumphorst A, Gianasmidis A, Rheinberger V. Comparative linear expansion study of various cements after water storage. J Dent Res 1998; 77:689.

22- Scientific documentation - ProTec Cem : research and development - scientific service 1998; 1-15.

23- Small ICB, Watson TF, Chadwick AV, Sidhu SK. Water sorption in resin-modified glass-ionomer cements: an in vitro comparison with other materials. Biomaterials 1998; 19:545-50.

24- Um CM, Oilo G. The effect of early water contact on glassionomer cements. Quintessence Int 1992; 23:209-14.

25- Uno S, Finger WJ, Fritz U. Long-term mechanical characteristics of resin-modified glass ionomer restorative materials. Dent Mater 1996; 12:64-9.

26- Williams JA, Billington RW. Changes in compressive strength of glass-ionomer restorative materials with respect to time periods of 24 h to months. J Oral Rehabil 1991; 18:163-8.

27- Wilson AD. Resin-modified glass-ionomer cements. Int J Prosthodont 1990; 3:425-9.

28- Wilson AD, McLean JW. Glass-ionomer cement. Chicago: Quintessence; 1988.

Recebido para publicação em: 28/08/2002

Aceito após reformulações em: 04/03/2003

Corresponding author:

Maria Fidela de Lima Navarro

Faculdade de Odontologia de Bauru - USP

Diretoria

Alameda Dr. Octávio Pinheiro Brisolla 9-75

CEP: 17012-901, Bauru SP Brazil

Phone: 14235 8295, Fax: 14223 4679, e-mail: mflnavar@usp.br 